\title{
Fish farms' threat to salmon stocks exposed
}

\section{Quirin Schiermeier}

Fears that the Atlantic salmon could become extinct were rekindled last week by a study on the effects of escaped farmed fish on wild fish populations.

The findings are expected to influence legislation in places such as Scotland, where farmed fish are often intentionally released for anglers. In addition, up to two million salmon are thought to escape from farms around the North Atlantic each year (see Nature 416, 571;2002).

Atlantic salmon are farmed mainly in Norway, Scotland, Ireland, Canada and the northeastern United States, using species bred from a few Norwegian strains for faster growth. This selection process makes the fish more economically valuable, but their unusual genes and their unfamiliarity with natural conditions make them vulnerable to predators and disease in the wild.

The new paper follows a ten-year study carried out in the Burrishoole river system in County Mayo, Ireland, a traditional centre for salmon research run by the Irish Marine Institute (P. McGinnity et al. Proc. R. Soc. Lond. B doi:10.1098/rspb.2003.2520; 2003). Researchers released known numbers of farmed salmon, along with eggs of wildfarmed hybrids, in a natural salmon-spawning river. They then recaptured fish in fresh water and at sea, and used DNA profiling to identify their parentage.

As expected, farmed fish were short-lived,

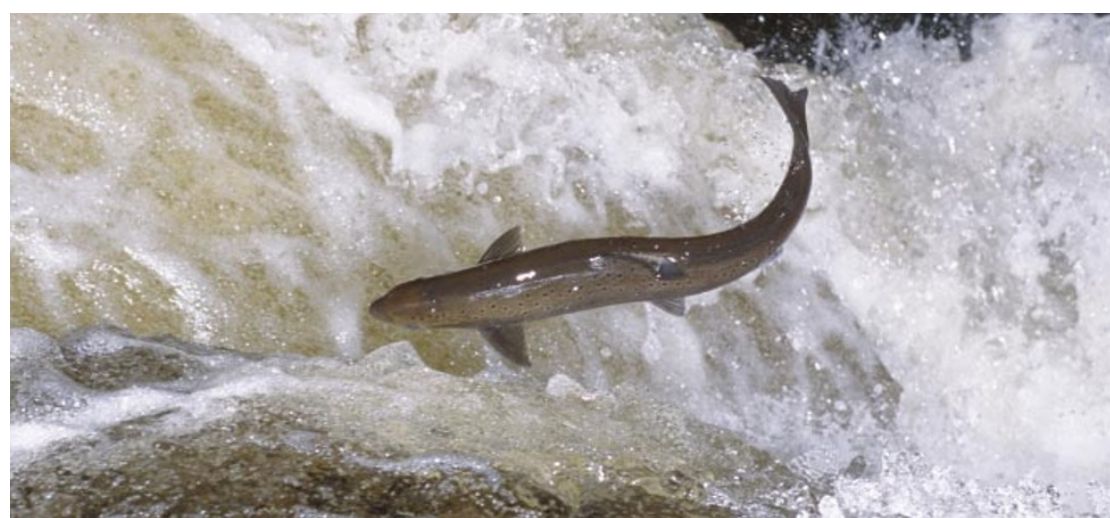

In at the deep end: farmed salmon don't live long in the wild, but their offspring dilute the gene pool.

surviving on average $2 \%$ as long as their wild counterparts. But those created by interbreeding became more likely to die in successive generations: hybrids survived $27-89 \%$ as long as their wild cousins, depending on their parentage and whether they were first- or second-generation offspring. The second generation fared particularly poorly: $70 \%$ of embryos died. "Additive genetic variations may finally cause the extinction of vulnerable populations," says Andy Ferguson, a fish geneticist at Queen's University Belfast, Northern Ireland, one of the authors of the new study.

The results provide clear evidence of how interbreeding can harm wild salmon, says Eric Verspoor, head of the fish-genetics group at the Fisheries Research Services' Freshwater Laboratory in Pitlochry, Scotland. It could devastate the beleaguered Atlantic salmon, which has already been hit by pollution and overfishing - wild stocks are extinct, endangered or vulnerable in more than half the 2,000 salmon-spawning rivers around the North Atlantic.

The Edinburgh-based North Atlantic Salmon Conservation Organisation is developing international guidelines for replenishing wild populations. Next year, the group will hold talks with the farming industry about improving containment. Meanwhile, Scottish angling organizations have pledged to alert clubs to the risk of restocking rivers with juvenile farmed salmon.

\section{Opossum hops over kangaroo to top of genome list}

\section{Carina Dennis, Sydney}

The humble opossum is set to become the first marsupial to have its genome sequenced disappointing Australian researchers who want to study the kangaroo.

But the US National

Human Genome Research Institute (NHGRI) in Bethesda, Maryland, which will lead the opossum effort, says that if the Australians raise the money to do half of the kangaroo sequence, it will complete the other half.

The South American grey short-tailed opossum (Monodelphis domestica), whose genome is roughly the same size as that of humans, joined the NHGRI's list of highpriority organisms on 14 October. "We expect sequencing to be under way within a year," says Francis Collins, director of the institute. The tammar wallaby (Macropus eugenii), a small kangaroo species, is ranked as a moderate priority.

Geneticists want a

marsupial genome sequence so that they can carry out comparative studies to identify new genes and investigate chromosome evolution. "Mice are too close to humans, and chickens are too far away for comparative genomics - marsupials are just right," says Jenny Graves, a geneticist at the Australian National University in Canberra.

"The tammar wallaby is a better choice because so much more is known about it in terms of physiology and genetics," says Graves. But she adds that she is excited about the possibility of funding for the kangaroo initiative, "as that means we could mount a big genomic enterprise in Australia. It would be a sad state of affairs if we couldn't even sequence our own national emblem."

The choice came down chiefly to the ease of working with opossums, researchers say. "There's no comparison - the opossum is much smaller, breeds prolifically and is easy and cheap to keep," says Paul Samollow, an evolutionary geneticist at the Southwest Foundation for Biomedical Research in San Antonio, Texas, which houses the oldest and largest opossum colony in captivity.

The US kangaroo offer depends upon Australia agreeing to do half of the sequence. An Australian centre for kangaroo genomics was set up in July with a government grant of A $\$ 3.3$ million (US\$2.3 million) over five years. But it won't have either the infrastructure or the funding to do the sequencing, which would have to take place at the government-supported Australian Genome Research Facility (AGRF).

"We'll need to raise close to A\$6 million," says Susan Forrest, director of the AGRF. While hoping for government support, she is also preparing to pass the hat around potential sponsors, including the airline Qantas, whose emblem is a kangaroo. 